\title{
Cardiac, Energy and Hormonal Blood Markers, and Lactatemia in Cows with Displaced Abomasum
}

\author{
Ana Clara Sarzedas Ribeiro', Gliére Silmara Leite Soares², Luiz Teles Coutinho ${ }^{3}$, \\ Jobson Filipe de Paula Cajueiro ${ }^{3}$, Rodolfo José Cavalcanti Souto ${ }^{3}$, Bruna Higino de Souza Silva², \\ Pierre Castro Soares ${ }^{4}$, Carla Lopes de Mendonça ${ }^{3} \&$ José Augusto Bastos Afonso ${ }^{3}$
}

\begin{abstract}
Background: Displaced abomasum (DA) is a common and economically important disorder that affects dairy cattle. Nutritional factors and adaptive responses that occur in the peripartum play a central role in the pathogenesis. The measurement of blood metabolites represents a useful tool for monitoring and prognostic determination in affected animals. Therefore, the objective was to evaluate cardiac, energy and hormonal blood markers, lactatemia, and insulin sensitivity in cows diagnosed with right displaced abomasum (RDA) and left displaced abomasum (LDA), comparing them with each other. Materials, Methods \& Results: Nineteen cases of abomasum displacement in cows were studied, including 9 cases of RDA and 10 cases of LDA. The diagnosis was established by means of physical examination and measurement of the concentration of chlorides in the ruminal fluid $(>30 \mathrm{mEq} / \mathrm{L})$. After diagnosis, clinical-surgical therapeutic management was instituted. At the time of diagnosis (M1) and at the resolution of the case (M2), blood samples were collected to assess the variables: non-esterified fatty acids (NEFA), beta hydroxybutyrate $(\beta \mathrm{HB})$, L-lactate, creatine kinase $(\mathrm{CK})$, creatine kinase MB (CK-MB), cardiac troponin I (cTnI), lactate dehydrogenase (LDH), glucose, insulin, and cortisol. In addition, insulin sensitivity was estimated using the Revised Quantitative Insulin Sensitivity Check Index (RQUICKI) and RQUICKI- $\beta$ HB. The means of the variables were compared, separating the effects of groups (RDA and LDA) and moments (M1 and M2), at the level of 5\% probability. The concentrations of NEFA, CK-MB, L-lactate, glucose, insulin, and cortisol were higher at $\mathrm{M} 1$ and the RQUICKI and RQUICKI- $\beta$ HB indices were lower at this moment. L-lactate, CK, and CK-MB were higher in the RDA group, while cTnI, $\beta \mathrm{HB}$, and LDH did not present a group or moment effect. Cardiac markers correlated with the energy profile metabolites, L-lactate, and cortisol.

Discussion: The high concentrations of NEFA at M1 reflected the condition of negative energy balance. $\beta \mathrm{HB}$ concentrations were stable, that may be related to the number of days postpartum in which the animals were diagnosed. The hyperglycemic condition and the increase in serum cortisol concentrations found at M1 can be induced by the condition of metabolic stress resulting from the disease. Hyperinsulinemia were recorded in the present study could be an important factor related to the pathogenesis of DA, since there seems to be a correlation between hyperinsulinemia and decreased abomasal emptying rate. The RQUICKI and RQUICKI- $\beta$ HB indices was significantly lower at M1, which may indicate lower sensitivity of peripheral tissues to insulin at this time. Changes in serum activity of LDH and CK may result from tissue damage due to organ displacement, in addition to damage associated with surgery and the administration of injectable drugs, mainly intramuscularly. The elevation in plasma L-lactate at M1 and in the RDA group may be associated with abomasal hypoperfusion. The high positive correlations found between L-lactate and the variables glucose, insulin, and cortisol reinforcing the association between the concentration of L-lactate and the moment of greatest stress. The increase in cardiac biomarkers may be related to the occurrence of ischemia/reperfusion injury in the abomasum, which involves oxidative stress and the production of inflammatory mediators. The hyperglycemic condition and the higher concentrations of NEFA can also contribute to the occurrence of myocardial injury. The correlations found between cardiac biomarkers and plasma L-lactate, strengthen the idea that there is a relationship between L-lactate and myocardial injury. In this sense, the measurement of blood concentrations of cTnI, CK-MB, and L-lactate could contribute as severity markers and prognosis indicators in cattle with DA.
\end{abstract}

Keywords: cardiac troponin I, creatine kinase MB, dairy cattle, insulin sensitivity, L-lactate, non-cardiac disease.

DOI: $10.22456 / 1679-9216.103310$

Received: 15 May 2020

Accepted: 19 July 2020

Published: 17 August 2020

${ }^{1}$ Programa de Pós-Graduação em Sanidade e Reprodução de Animais de Produção, Unidade Acadêmica de Garanhuns (UAG), campus da Universidade Federal Rural de Pernambuco (UFRPE), Garanhuns, PE, Brazil. ${ }^{2}$ Programa de Pós-Graduação em Medicina Veterinária \& ${ }^{4}$ Departamento de Medicina Veterinária, UFRPE, Recife, PE. ${ }^{3}$ Clínica de Bovinos de Garanhus (CBG), campus da UFRPE, Garanhuns. CORRESPONDENCE: A.C.S. Ribeiro [ac_sarzedas@id.uff.br]. CBG/UFRPE. Av. Bom Pastor s/n. CEP 55292-272 Garanhuns, PE, Brazil. 


\section{INTRODUCTION}

Displaced abomasum (DA) is a common and economically important disorder that affects high-producing dairy cattle, especially in the first month of lactation [36]. The disease, which has a multifactorial etiology, can be classified as left displaced abomasum (LDA), right displaced abomasum (RDA), and abomasal volvulus (AV). Nutritional factors play a central role in the pathogenesis and any concomitant conditions or diseases that cause gastrointestinal hypomotility can cause the disorder $[9,25]$. The adaptive responses that occur in the peripartum, such as hormonal and energy metabolism alterations, also deserve to be highlighted in their pathogenesis [21,36].

Historically, the prognosis of cattle with DA has been supported mainly by clinical variables, with the use of blood metabolites being more recent. Elevated plasma concentration of L-lactate has been linked to severity in different diseases in humans and animals, making it an important tool for evaluating therapeutic response and prognosis $[2,3,14,27]$. Recently, cardiac troponin I (cTnI) and creatine kinase MB (CK-MB), have also been studied in different species in order to monitor myocardial integrity and establish the prognosis in primary cardiac disorders and diseases of noncardiac origin [22,27,34]. A few studies have shown the association of blood concentrations of cTnI, CK-MB, and L-lactate with prognosis in cows affected by DA $[5,7,14,22,34]$. However, in Brazil, there is no report on the analysis of these markers in cattle with DA.

The aim of this study was to evaluate cardiac, energy and hormonal markers, as well as L-lactate in the blood of cows diagnosed with RDA and LDA, comparing them with each other.

\section{MATERIALS AND METHODS}

\section{Animals}

A study of 19 cases of displaced abomasum in cows was carried out, with 9 cases of RDA (including three cases of AV) and 10 cases of LDA. The animals used were treated at the Garanhuns Bovine Clinic, Federal Rural University of Pernambuco Campus, Garanhuns-PE, Brazil, with a mean age of 3.6 years in the RDA group and 4.8 years in the LDA group. The majority of animals were crossbred, from the crossbreeding of dairy breeds (Holstein-Gir), kept in a semi-intensive system, and were in the first trimester of lactation, with a mean number of 60 and 90 days postpartum, in the RDA and LDA groups, respectively.
Diagnosis

The diagnosis of displacement of the abomasum was established by means of physical examination and measurement of the concentration of chlorides in the ruminal fluid, where concentrations greater than $30 \mathrm{mEq} / \mathrm{L}$ were considered indicative of reflux of the abomasal content into the rumen, resulting from the displacement of the organ [11].

\section{Treatment}

After diagnosis, clinical-surgical therapeutic management was instituted, based on surgical correction of DA by pyloro-omentopexy [4] and postoperative clinical treatment with meloxicam ${ }^{1}$ Maxicam $^{\circledR}$ : $0.5 \mathrm{mg} / \mathrm{Kg}$, IV, SID, 5 days), oxytetracycline ${ }^{2}$ (Terramicina/LA ${ }^{\circledR}: 20 \mathrm{mg} / \mathrm{Kg}$, IM, every 72 h, 3 applications), exclusive supply of grasses (Pennisetum purpureum, Cynodon spp., Brachiaria decumbens), hydroelectrolytic replacement, and rumen transfaunation.

\section{Blood biochemistry}

At the time of diagnosis (M1) and at the resolution of the case (M2), blood samples were collected by venipuncture of the jugular, in sterile vacuum tubes (Vacutainer System $\left.{ }^{\circledR}\right)^{3}$ without anticoagulant and with sodium fluoride/potassium oxalate, to obtain serum and plasma, respectively. Resolution of the case was considered as hospital discharge or euthanasia due to the severity of the clinical case. The samples were fractionated in aliquots and stored in a freezer at $-80^{\circ} \mathrm{C}$ for further laboratory processing.

The blood metabolites analyzed were: non-esterified fatty acids $\left(\text { NEFA assay }{ }^{\circledR}\right)^{4}$, beta hydroxybutyrate (D-3-Hydroxybutyrate/Ranbut assay $\left.{ }^{\circledR}\right)^{4}$, L-lactate (Enzyme Lactate $\left.{ }^{\circledR}\right)^{5}$, creatine kinase (CK-NAC Liquiform $\left.^{\circledR}\right)^{5}$, lactate dehydrogenase (LDH Liquiform $\left.{ }^{\circledR}\right)^{5}$, and glucose (Glucose Liquiform $\left.{ }^{\circledR}\right)^{5}$ in a semi-automatic biochemical analyzer $\left(\mathrm{BIO} 2000^{\circledR}\right)^{6}$. The serum activity of CK-MB (CK-MB Liquiform $\left.{ }^{\circledR}\right)^{5}$ was determined using an automatic biochemical analyzer (Labmax $\left.240^{\circledR}\right)^{5}$. The serum concentrations of cTnI and the hormones insulin and cortisol were determined by chemiluminescent immunoassay using commercial kits (Access Immunoassay Systems $\left.{ }^{\circledR}\right)^{7}$.

Insulin Sensitivity Index

Insulin sensitivity was estimated using the Revised Quantitative Insulin Sensitivity Check Index (RQUICKI) and RQUICKI- $\beta$ HB, which takes into 
account the concentration of glucose, insulin, nonesterified fatty acids (NEFA), and beta hydroxybutyrate $(\beta \mathrm{HB})$ according to the equations: RQUICKI $=1 /$ [ $\log 10$ (glucose $\mathrm{mg} \mathrm{dL}^{-1}$ ) $+\log 10$ (insulin $\mu \mathrm{U} \mathrm{mL}^{-1}$ ) $+\log 10\left(\right.$ NEFA mmol L $\left.\left.{ }^{-1}\right)\right]$ and RQUICKI- $\beta \mathrm{HB}=1 /$ $\left[\log 10\left(\right.\right.$ glucose $\left.\mathrm{mg} \mathrm{dL}^{-1}\right)+\log 10$ (insulin $\mu \mathrm{U} \mathrm{mL}^{-1}$ ) $+\log 10\left(\right.$ NEFA mmol L $\left.\left.{ }^{-1}\right)+\log 10\left(\beta \mathrm{HB}_{\mathrm{mmol} \mathrm{L}}^{-1}\right)\right]$ [12].

\section{Statistical analysis}

Initially, the data were tested for normality and homoscedasticity, using the Kolmogorov-Smirnov and Bartlett tests, respectively. Those that did not meet these premises were submitted to logarithmic or square root transformation. Subsequently, the data that met the premises of normality and homoscedasticity were subjected to ANOVA by the GLM procedure, which separated, as sources of variation, the effects of the RDA and LDA groups and moments M1 and M2. When significance was observed, the means were compared by the F test. Data that did not meet the premises of normality and homoscedasticity after the appropriate transformations were subjected to the Mann Whitney non-parametric test. In addition, correlations between pairs of variables were estimated by calculating the Pearson's correlation coefficient, using general data without separation by group. For all analyzes, the significance level $(P)$ of $5 \%$ was considered. Data were analyzed using the Minitab $18^{\circledR}$ statistical program ${ }^{8}$.

\section{RESULTS}

The mean hospital stays were 8 and 10 days for RDA and LDA, respectively. With respect to clinical resolution, $94.7 \%$ (18/19) of the animals were discharged after treatment and only one animal in the RDA group was euthanized.

When evaluating the moment effect, a difference was observed for the NEFA $(P=0.0054)$, CK-MB $(P=0.0084)$, L-lactate $(P=0.0024)$, glucose $(P=0.0012)$, insulin $(P=0.0021)$, and cortisol $(P<.0001)$, which were higher at M1, and for the RQUICKI $(P<.0001)$ and RQUICKI- $\beta$ HB indices $(P=0.0015)$, which presented lower means at this moment (Table 1).

Regarding the group effect, a difference was found for the variables CK $(P=0.0021), \mathrm{CK}-\mathrm{MB}(P=$ $0.0249)$, and L-lactate $(P=0.0510)$, which were higher in the RDA group. The concentrations of $\mathrm{cTnI}$ and $\beta \mathrm{HB}$ and the serum LDH activity did not differ $(P>0.05)$ between groups or moments (Table 1).

In the correlation analysis, the following results were highlighted: L-lactate $\mathrm{x}$ glucose $(\mathrm{r}=0.73$; $P<0.001)$, L-lactate $\mathrm{x}$ insulin $(\mathrm{r}=0.63 ; P<0.001)$, L-lactate $\mathrm{x}$ cortisol $(\mathrm{r}=0.89 ; P<0.001)$, cTnI x CKMB (r = 0.543; $P<0.001)$, cTnI x L-lactate $(\mathrm{r}=0.46$; $P=0.004), \mathrm{cTnI} \times \mathrm{LDH}(\mathrm{r}=0.50 ; P=0.001), \mathrm{cTnI}$ $\mathrm{x}$ glucose $(\mathrm{r}=0.44 ; P=0.006)$, cTnI x cortisol $(\mathrm{r}=$ $0.53 ; P=0.001)$, CK-MB x L-lactate $(\mathrm{r}=0.42 ; P=$ 0.010), CK-MB x LDH ( $\mathrm{r}=0.41 ; P=0.011)$, CK-MB $\mathrm{x}$ glucose $(\mathrm{r}=0.39 ; P=0.016)$, and $\mathrm{CK}-\mathrm{MB} \mathrm{x}$ cortisol (r $=0.37 ; P=0.022)$.

\section{DISCUSSION}

The high concentrations of NEFA at the time of diagnosis reflected the condition of negative energy balance (NEB) faced by animals affected by DA, regardless of type. This condition has been reported by several authors $[10,17,31,36,38]$ and is justified by the reduced dry matter intake, commonly presented by animals affected by the disease, which becomes insufficient to meet the energy demand for milk production. This fact is considered an essential element in the etiology of DA [21].

$\beta \mathrm{HB}$ concentrations were stable between groups and moments, demonstrating only slightly higher values than those reported by Silva Filho et al. [28] in healthy dairy cattle at 60 days postpartum. Despite the slight elevation, these values remained within normal limits, thus excluding the possibility of concomitant diagnosis of clinical ketosis in the animals in this study. Diverging from these findings, some authors have recorded higher $\beta \mathrm{HB}$ concentrations in animals with DA than in control groups $[10,17,38]$. However, this divergence may be related to the number of days postpartum in which the animals were diagnosed, considering that animals with DA presented significantly higher concentrations of $\beta \mathrm{HB}$ than controls in the period between 2 and 28 days postpartum, while animals diagnosed between 29 and 56 days postpartum, a period that is close to our result, showed lower concentrations of $\beta \mathrm{HB}$, not significantly different from the control [31].

The hyperglycemic condition found in animals with DA at the time of diagnosis was also reported by Zadnik [38]. Although there was no interaction, it 
A.C.S. Ribeiro, G.S.L. Soares, L.T. Coutinho, et al. 2020. Cardiac, Energy and Hormonal Blood Markers, and Lactatemia in Cows with Displaced Abomasum.

Table 1. Mean, standard deviation, and general mean values of blood metabolites and insulin sensitivity indices of cows with RDA $(n=9)$ and LDA $(n=10)$, at the moment of diagnosis and resolution of the cases.

\begin{tabular}{|c|c|c|c|c|}
\hline Variable & Group & M1 & M2 & GM \\
\hline \multirow{3}{*}{ NEFA $\left(\mathrm{mmol} \mathrm{L}^{-1}\right)^{*}$} & RDA & $0.99 \pm 0.38$ & $0.56 \pm 0.45$ & \multirow{3}{*}{$\begin{array}{l}0.78^{\mathrm{A}} \\
0.63^{\mathrm{A}}\end{array}$} \\
\hline & LDA & $0.86 \pm 0.65$ & $0.39 \pm 0.29$ & \\
\hline & GM & $0.92^{\mathrm{a}}$ & $0.47^{\mathrm{b}}$ & \\
\hline \multirow{3}{*}{$\beta \mathrm{HB}\left(\mathrm{mmol} \mathrm{L}^{-1}\right)^{* *}$} & RDA & $0.52 \pm 0.27$ & $0.50 \pm 0.09$ & \multirow{3}{*}{$\begin{array}{l}0.51^{\mathrm{A}} \\
0.56^{\mathrm{A}}\end{array}$} \\
\hline & LDA & $0.68 \pm 0.38$ & $0.44 \pm 0.12$ & \\
\hline & GM & $0.61^{\mathrm{a}}$ & $0.47^{\mathrm{a}}$ & \\
\hline \multirow{3}{*}{$\mathrm{cTnI}\left(\mathrm{ng} \mathrm{mL} \mathrm{m}^{-1}\right)^{* *}$} & RDA & $0.17 \pm 0.20$ & $0.03 \pm 0.02$ & \multirow{3}{*}{$\begin{array}{l}0.10^{\mathrm{A}} \\
0.04^{\mathrm{A}}\end{array}$} \\
\hline & LDA & $0.06 \pm 0.05$ & $0.03 \pm 0.01$ & \\
\hline & GM & $0.11^{\mathrm{a}}$ & $0.03^{\mathrm{a}}$ & \\
\hline \multirow{3}{*}{ CK-MB $\left(\mathrm{ng} \mathrm{mL}^{-1}\right)^{*}$} & RDA & $178.09 \pm 98.85$ & $77.84 \pm 65.28$ & \multirow{3}{*}{$\begin{array}{c}127.96^{\mathrm{A}} \\
80.31^{\mathrm{B}}\end{array}$} \\
\hline & LDA & $119.08 \pm 119.73$ & $41.54 \pm 26.88$ & \\
\hline & GM & $147.03^{\mathrm{a}}$ & $58.74^{\mathrm{b}}$ & \\
\hline \multirow{3}{*}{$\mathrm{CK}\left(\mathrm{U} \mathrm{L}^{-1}\right)^{*}$} & RDA & $1044.26 \pm 1178.60$ & $350.78 \pm 253.57$ & \multirow{3}{*}{$\begin{array}{l}697.52^{\mathrm{A}} \\
259.87^{\mathrm{b}}\end{array}$} \\
\hline & LDA & $386.17 \pm 577.22$ & $133.57 \pm 85.86$ & \\
\hline & GM & $697.89^{\mathrm{a}}$ & $236.46^{\mathrm{a}}$ & \\
\hline \multirow{3}{*}{ L-lactate $\left(\mathrm{mmol} \mathrm{L}^{-1}\right)^{* *}$} & RDA & $3.28 \pm 3.32$ & $0.93 \pm 1.17$ & \multirow{3}{*}{$\begin{array}{l}2.11^{\mathrm{A}} \\
0.92^{\mathrm{B}}\end{array}$} \\
\hline & LDA & $1.09 \pm 0.59$ & $0.77 \pm 0.37$ & \\
\hline & GM & $2.18^{\mathrm{a}}$ & $0.85^{\mathrm{b}}$ & \\
\hline \multirow{3}{*}{$\mathrm{LDH}\left(\mathrm{U} \mathrm{L}^{-1}\right)^{*}$} & RDA & $1798.39 \pm 847.71$ & $1199.84 \pm 356.65$ & \multirow{3}{*}{$\begin{array}{l}1499.1^{\mathrm{A}} \\
1476.6^{\mathrm{A}}\end{array}$} \\
\hline & LDA & $1482.40 \pm 546.51$ & $1470.80 \pm 459.93$ & \\
\hline & GM & $1632.08^{\mathrm{a}}$ & $1342.45^{\mathrm{a}}$ & \\
\hline \multirow{3}{*}{ Glucose $\left(\mathrm{mg} \mathrm{dL}^{-1}\right) * *$} & RDA & $119.94 \pm 83.69$ & $56.45 \pm 20.30$ & \multirow{3}{*}{$\begin{array}{l}88.19^{\mathrm{A}} \\
55.80^{\mathrm{A}}\end{array}$} \\
\hline & LDA & $63.42 \pm 13.97$ & $48.95 \pm 5.71$ & \\
\hline & GM & $91.68^{\mathrm{a}}$ & $52.50^{\mathrm{b}}$ & \\
\hline \multirow{3}{*}{ Insulin $\left(\mathrm{pmol} \mathrm{L}^{-1}\right)^{*}$} & RDA & $8.75 \pm 11.04$ & $3.52 \pm 2.39$ & \multirow{3}{*}{$\begin{array}{l}6.13^{\mathrm{A}} \\
5.90^{\mathrm{A}}\end{array}$} \\
\hline & LDA & $9.38 \pm 6.30$ & $2.41 \pm 0.66$ & \\
\hline & GM & $9.08^{\mathrm{a}}$ & $2.94^{\mathrm{b}}$ & \\
\hline \multirow{3}{*}{ Cortisol $\left(\mathrm{nmol} \mathrm{L}^{-1}\right)^{*}$} & RDA & $325.57 \pm 425.10$ & $24.95 \pm 24.93$ & \multirow{3}{*}{$\begin{array}{c}175.26^{\mathrm{A}} \\
57.44^{\mathrm{A}}\end{array}$} \\
\hline & LDA & $95.10 \pm 87.87$ & $19.78 \pm 15.58$ & \\
\hline & GM & $204.27^{\mathrm{A}}$ & $22.23^{\mathrm{b}}$ & \\
\hline \multirow{3}{*}{ RQUICKI** } & RDA & $0.57 \pm 0.13$ & $1.44 \pm 0.94^{\mathrm{Aa}}$ & \multirow{3}{*}{$\begin{array}{l}1.01^{\mathrm{A}} \\
1.32^{\mathrm{A}}\end{array}$} \\
\hline & LDA & $0.76 \pm 0.37$ & $1.94 \pm 1.66^{\mathrm{Aa}}$ & \\
\hline & GM & $0.67^{\mathrm{b}}$ & $1.69^{\mathrm{a}}$ & \\
\hline \multirow{3}{*}{ RQUICKI- $\beta$ HB** } & RDA & $0.74 \pm 0.26$ & $0.84 \pm 3.81$ & \multirow{3}{*}{$\begin{array}{l}0.79^{\mathrm{A}} \\
1.71^{\mathrm{A}}\end{array}$} \\
\hline & LDA & $0.78 \pm 0.31$ & $2.64 \pm 4.98$ & \\
\hline & GM & $0.74^{\mathrm{b}}$ & $1.74^{\mathrm{a}}$ & \\
\hline
\end{tabular}

RDA: right displaced abomasum; LDA: left displaced abomasum; GM: general mean; RQUICKI: Revised Quantitative Insulin Sensitivity Check Index. *ANOVA; **Mann-Whitney. ${ }^{\mathrm{A}, \mathrm{B}}$ Different capital letters in the same column indicate significant differences between groups $(P<0.05)$. ${ }^{\mathrm{a}, \mathrm{b}}$ Different lower case letters on the same line indicate significant differences between moments $(P<0.05)$.

appears that numerically the mean glucose in animals with RDA was higher. In this clinical condition, hyperglycemia may be associated with decreased pancreatic juice flow and impaired blood circulation in the pancreatic parenchyma, due to alterations in the positioning of the duodenal segment and omentum, which occur during organ displacement [38]. However, the hyperglycemic state can also be justified by the increase in serum cortisol concentrations, induced by the condition of metabolic stress resulting from the disease, as occurs in cases of clinical ketosis [30]. In the current study, animals with RDA presented much higher mean 
cortisol concentrations than the LDA group at the time of diagnosis, demonstrating a greater degree of stress in this clinical condition. In contradiction to these findings, van Winden et al. [36] reported lower glucose concentrations in animals with LDA when compared to control groups and attributed this condition to the decrease in food consumption that occurs due to NEB, which can intensify significantly from the fourth day before the diagnosis of this disease.

Associated with the hyperglycemic condition, high insulin concentrations were also recorded in the present study, as described by van Meirhaeghe et al. [23]. These authors also found that despite the high levels of insulin in these animals, glucose metabolization occurred more slowly, which points to a possible decrease in body tissue sensitivity to insulin. Hyperinsulinemia could be an important factor related to the pathogenesis of DA, since van Meirhaeghe et al. $[23,24]$ found a clear correlation between hyperinsulinemia and decreased abomasal emptying rate. For these researchers, disturbances in the production of insulinogenic substances, such as butyrate and valerate fatty acids, which are able to induce a much more pronounced insulin response than glucose, may play an important role in the pathogenesis of DA. In addition, for these authors, the glycemic status is not related to the rate of emptying of the abomasum, considering that they observed a marked inhibition of abomasal emptying in both conditions of hypoglycemia and hyperglycemia. In contrast to the previous conclusion, Holtenius et al. [16] have suggested that both hyperinsulinemia and hyperglycemia may play an important role in the pathogenesis of DA, however, these authors state that the mechanisms that mediate the effect of hyperglycemia on the abomasum emptying rate are not yet understood.

In the present study, tissue sensitivity to insulin estimated by the RQUICKI and RQUICKI- $\beta \mathrm{HB}$ indices was significantly lower at the time of diagnosis compared to M2, which may indicate lower sensitivity of peripheral tissues to insulin at this time, as previously reported [23]. Cows with DA tended to present lower values of the RQUICKI index when compared to animals in the control group, thus implying that cows with DA may have reduced insulin sensitivity [31]. The decrease in the sensitivity of peripheral tissues to insulin intensifies with the increased mobilization of adipose tissue, as observed in the current study, which in turn is responsible for inhibiting glucose uptake stimulated by insulin through decreases in the expression of GLUT 4 molecules.

The serum activity of lactate dehydrogenase (LDH) was high at both moments and in both groups, with no statistical differences, corroborating with Maden et al. [22] who found high values of this enzyme in cattle with RDA and LDA. LDH is high in several tissues of the body, mainly skeletal and cardiac muscles, liver, and erythrocytes, in addition to kidneys, bones, and lungs, making it highly nonspecific. Considering the moderate correlations between LDH, CK-MB, and cTnI, it is possible that the increase in the activity of this enzyme in the current study is associated with cardiac injury, however only measurement of LDH isoenzymes could provide accurate information on the origin of the lesions and these tests are not commonly performed in the veterinary routine. In addition, more specific blood biomarkers are available to assess muscle and cardiac lesions, such as cTnI and CK-MB, used in the current study [33].

Although there was no significant difference between the moments, the serum activity of the CK enzyme was above normal values for the species from M1 to the resolution of cases, with this increase being more expressive in the RDA group. As CK is a musclespecific enzyme, this elevation indicates the occurrence of muscle damage [33]. Maden et al. [22] have also observed higher CK serum activity in cattle with RDA compared to LDA. The greater increase in CK activity in cases of RDA, compared to cases of LDA, may result from more severe tissue damage to the organ wall in disorders on the right. Another relevant factor is the maintenance of high values of this variable up to M2, which could be related to tissue damage associated with surgery and the administration of injectable drugs in the postoperative period, mainly through the intramuscular route.

The elevation in plasma L-lactate at M1 and in the RDA group may be associated with abomasal hypoperfusion due to excessive distension of the wall and displacement of the organ from its anatomical position, especially in cases of RDA and AV in which the circulatory impairment is more severe. The main cause of hyperlactatemia is tissue hypoxia and this metabolite, produced during anaerobic glycolysis, is a sensitive marker of hypoperfusion [2]. Abomasal perfusion decreases as luminal pressure increases, 
resulting in ischemia and necrosis of the organ wall. Wittek et al. [37] found that the gas pressure in the abomasal lumen is positively correlated with plasma lactate concentration and negatively correlated with abomasal oxygen saturation.

Elevated plasma lactate has been reported in dairy cows with DA, being an important prognostic indicator in cases of RDA or AV [5,7,10,14]. Lactate concentrations $\leq 2 \mathrm{mmol} / \mathrm{L}$ present good predictive value for a positive result and represent a useful tool to support the surgical correction of abomasal disorders. On the other hand, cows with lactate $\geq 6 \mathrm{mmol} / \mathrm{L}$ demonstrated a high probability of negative results after surgery [5]. The fact that the mean plasma L-lactate at M1 was $2.18 \mathrm{mmol} / \mathrm{L}$ and that $94.7 \%$ of the animals were discharged after treatment confirm the association between lactatemia and prognosis proposed by these authors. The high positive correlations found between L-lactate and the variables glucose $(\mathrm{r}=0.73$; $P<0.001)$, insulin $(\mathrm{r}=0.63 ; P<0.001)$, and cortisol ( $\mathrm{r}=0.89 ; P<0.001)$, should also be highlighted, reinforcing the association between the concentration of L-lactate and the moment of greatest stress in animals affected by DA. The reduction in L-lactate at M2, returning to physiological values, is related to tissue reperfusion of the abomasum after surgical correction.

The increase in CK-MB concentrations at M1 and reduction at M2 suggest the occurrence of some degree of myocardial injury associated with the most critical moment of the disease. Although the cardiospecificity of CK-MB is reduced, when compared to cTnI, a moderate correlation was observed $(\mathrm{r}=0.54$; $P=0.000$ ) between these biomarkers. In humans and different animal species, CK-MB and cTnI have been used for diagnosis, monitoring, and prognostic determination in critically ill patients affected by primary cardiac and other non-cardiac diseases [1,27,29,34]. Elevated CK-MB activity has been reported in cattle with RDA when compared to healthy animals and those with LDA [22], as in the present study, in which the CK-MB activity was also greater in the RDA group.

Although without statistical differences between groups and moments, the clinical condition presented triggered a marked increase in the mean serum concentration of cTnI at M1 in animals with DA. However, it is worth mentioning that the highest mean value of cTnI at M1 was mainly due to the value recorded in the only animal $\left(0.61 \mathrm{ng} \mathrm{mL}^{-1}\right)$ for which euthanasia was recommended, due to the severity of the clinical condition, corroborating with Varga et al. [34] who also found higher concentrations of this biomarker in cows with DA and other non-cardiac diseases, associating this elevation with severity and an unfavorable prognosis.

The increase in these biomarkers in DA cows may be related to the occurrence of ischemia/reperfusion (I/R) injury in the abomasum. I/R-induced gastric injury involves oxidative stress and the production of inflammatory mediators $[19,20]$. The occurrence of oxidative stress and acute phase inflammatory response associated with elevated CK-MB was found in DA cases [22]. I/R injury can cause systemic oxidative stress due to the excessive production of reactive oxygen species (ROS), mainly through the xanthine oxidase pathway. ROS cause cytotoxicity through oxidative damage to proteins, carbohydrates, and cellular nucleic acids and through the peroxidation of membrane phospholipids, resulting in structural alterations and increased membrane permeability to cytosolic constituents and cell death $[8,32]$.

Another factor considered by some authors is that gastric injury through I/R also induces an increase in the synthesis of pro-inflammatory cytokines, highlighting the tumor necrosis factor alpha (TNF- $\alpha$ ) which is involved in the activation of neutrophils, leukocyte adhesion to endothelial cells, and stimulation of the production of other inflammatory cytokines, playing a fundamental role in the inflammatory response and tissue damage $[1,20]$. Exposure to TNF- $\alpha$ markedly increases endothelial permeability [6]. ROS also act as second messengers in intracellular signaling pathways, contributing to the continuous production of inflammatory cytokines and to systemic inflammation [8]. In this sense, the alterations observed in the present study may be associated with oxidative stress and a systemic inflammatory condition that cause damage to cardiomyocytes with extravasation and increased serum concentration of cardiac injury biomarkers.

The hyperglycemic condition found at M1 in animals with RDA in the current study, may contribute to the occurrence of oxidative stress and myocardial injury, as reported in humans [26] and ratified by the moderate correlations found between the biomarkers of cardiac injury, glucose, and cortisol: CK-MB x glucose ( $\mathrm{r}=0.39 ; P=0.016), \mathrm{CK}-\mathrm{MB}$ x cortisol $(\mathrm{r}=0.37 ; P=$ $0.022), \mathrm{cTnI} x$ glucose $(\mathrm{r}=0.44 ; P=0.006)$, and $\mathrm{cTnI}$ $\mathrm{x}$ cortisol $(\mathrm{r}=0.53 ; P=0.001)$. 
Another factor that should be considered is lipotoxicity, since lipolysis associated with NEB increases the availability of NEFA to cardiac cells [35]. In addition, the incorporation of these fatty acids and the formation of micelles in the plasma membrane of the myocardium cause destabilization, rupture of the membrane, and subsequent leakage of cardiac biomarkers [15].

The moderate correlations found between cardiac biomarkers and plasma L-lactate - CK-MB $\mathrm{x}$ L-lactate $(\mathrm{r}=0.42 ; P=0.010)$ and $\mathrm{cTnI} x$ L-lactate $(\mathrm{r}=0.46 ; P=0.004)$, strengthen the idea that there is a relationship between L-lactate and myocardial injury, previously proposed by different authors. In horses with colic undergoing emergency abdominal surgery, increases in L-lactate and cTnI were observed, and both were higher in the animals that did not survive surgical treatment [27]. In sheep with acute ruminal acidosis, hyperlactatemia and a significant negative correlation $(\mathrm{r}=-0.85 ; P=0.004)$ were reported between ruminal $\mathrm{pH}$ and serum L-lactate levels, as well as elevation in CK-MB and cTnI [13]. In humans, blood L-lactate has been shown to be a marker of risk stratification and mortality in patients with heart disease [18]. In this sense, the measurement of blood concentrations of cTnI, CK-MB, and L-lactate could contribute as severity markers and prognosis indicators in cattle with DA.

\section{CONCLUSION}

The animals diagnosed with abomasal displacement presented negative energy balance, with a high degree of stress, hyperlactatemia, and some degree of cardiac injury, these alterations being more intense in animals with right displaced abomasum. Thus, the importance of blood biomarkers, especially cTnI, CK-MB, and L-lactate as indicators of the prognosis of the disease, is reaffirmed. Additional studies are recommended to determine cut-off points and to evaluate the clinical and prognostic use of these markers in cattle with displaced abomasum.

\author{
MANUFACTURERS \\ ${ }^{1}$ Ourofino Saúde Animal. Cravinhos, SP, Brazil. \\ ${ }^{2}$ Zoetis Inc. Parsippany-Troy Hills Morris, NJ, USA. \\ ${ }^{3}$ Becton Dickinson Ind. Cir. Ltd. Franklin Lakes, NJ, USA. \\ ${ }^{4}$ Randox Laboratories Ltd. Crumlin, Northern Ireland, UK. \\ ${ }^{5}$ Labtest Diagnóstica S.A. Lagoa Santa, MG, Brazil. \\ ${ }^{6}$ Bioplus Produtos Para Laboratórios Ltda. Barueri, SP, Brazil. \\ ${ }^{7}$ Beckman Coulter Inc. Brea, CA, USA. \\ ${ }^{8}$ Minitab Inc. State College, PA, USA.
}

Declaration of interest. The authors report no conflicts of interest. The authors alone are responsible for the content and writing of paper.

\section{REFERENCES}

1 Alatassi A., Habbal M., Tamim H., Sadat M., Al Qasim E. \& Arabi Y.M. 2018. Association between troponin-I levels and outcome in critically ill patients admitted to non-cardiac intensive care unit with high prevalence of cardiovascular risk factors. BMC Anesthesiology. 18(1): 1-11. DOI: 10.1186/s12871-018-0515-7

2 Allen S.E. \& Holm J.L. 2008. Lactate: physiology and clinical utility. Journal of Veterinary Emergency and Critical Care. 18(2): 123-132. DOI: 10.1111/j.1476-4431.2008.00286.x

3 Bakker J., Nijsten M.W. \& Jansen T.C. 2013. Clinical use of lactate monitoring in critically ill patients. Annals of Intensive Care. 3(1): 12. DOI: 10.1186/2110-5820-3-12

4 Bartlett P.C., Kopcha M., Coe P.H., Ames N.K., Ruegg P.L. \& Erskine R.J. 1995. Economic comparison of the pyloro-omentopexy vs the roll-and-toggle procedure for treatment of left displacement of the abomasum in dairy cattle. Journal of the American Veterinary Medical Association. 206(6): 1156-1162.

5 Boulay G., Francoz D., Doré E., Dufour S., Veillette M., Badillo M., Bélanger A.M. \& Buczinski S. 2014. Preoperative cow-side lactatemia measurement predicts negative outcome in Holstein dairy cattle with right abomasal disorders. Journal of Dairy Science. 97(1): 212-221. DOI: 10.3168/jds.2013-6898

6 Brett J., Gerlach H., Nawroth P., Steinberg S., Godman G. \& Stern D. 1989. Tumor necrosis factor/cachectin increases permeability of endothelial cell monolayers by a mechanism involving regulatory G proteins. The Journal of Experimental Medicine. 169(6): 1977-1991. DOI: 10.1084/jem.169.6.1977

7 Buczinski S., Boulay G. \& Francoz D. 2015. Preoperative and Postoperative L-Lactatemia Assessment for the Prognosis of Right Abomasal Disorders in Dairy Cattle. Journal of Veterinary Internal Medicine. 29(1): 375-380. DOI: $10.1111 /$ jvim. 12490 
8 Bulger E. \& Maier R. 2001. Antioxidants in Critical Illness. Archives of Surgery. 136(10): 1201. DOI: 10.1001/archsurg.136.10.1201

9 Câmara A.C.L., Afonso J.A.B., Costa N.A., Mendonça C.L., Souza M.I. \& Borges J.R.J. 2010. Fatores de risco, achados clínicos, laboratoriais e avaliação terapêutica em 36 bovinos com deslocamento de abomaso. Pesquisa Veterinária Brasileira. 30(5): 453-464. DOI: 10.1590/S0100-736X2010000500014

10 Cardoso F.C., Esteves V.S., Oliveira S.T., Lasta C.S., Valle S.F., Campos R. \& González F.H.D. 2008. Hematological, biochemical and ruminant parameters for diagnosis of left displacement of the abomasum in dairy cows from Southern Brazil. Pesquisa Agropecuária Brasileira. 43(1): 141-147. DOI: 10.1590/S0100-204X2008000100018

11 Dirksen G. 1993. Sistema Digestivo. In: G. Dirksen G., Günder H.D. \& Stöber M. (Eds). Rosenberger Exame Clínico dos Bovinos. 3.ed. Rio de Janeiro: Guanabara Koogan, pp.163-224.

12 Djoković R., Dosković V., Cincović M., Belić B., Fratrić N., Jašović B. \& Lalović M. 2017. Estimation of Insulin Resistance in Healthy and Ketotic Cows during an Intravenous Glucose Tolerance Test. Pakistan Veterinary Journal. 37(4): 387-392.

13 Fartashvand M. \& Haji-Sadeghi Y. 2017. Evaluation of serum cardiac biomarkers in sheep with acute lactic acidosis. Journal of the Hellenic Veterinary Medical Society. 68(2): 219-224. DOI: 10.12681/jhvms.15608

14 Figueiredo M.D., Nydam D.V., Perkins G.A., Mitchell H.M. \& Divers T.J. 2006. Prognostic Value of Plasma LLactate Concentration Measured Cow-Side with a Portable Clinical Analyzer in Holstein Dairy Cattle with Abomasal Disorders. Journal of Veterinary Internal Medicine. 20(6): 1463-1470. DOI: 10.1111/j.1939-1676.2006.tb00767.x

15 Gerede D.M., Kozluca V., Esenboğa K., Aydoğan B.İ. \& Tutar E. 2016. Markedly Elevated Troponin in Diabetic Ketoacidosis without Acute Coronary Syndrome. Turkish Journal of Endocrinology and Metabolism. 20(2): 58-60. DOI: $10.4274 /$ tjem.2997

16 Holtenius K., Sternbauer K. \& Holtenius P. 2000. The effect of the plasma glucose level on the abomasal function in dairy cows. Journal of Animal Science. 78(7): 1930-1935. DOI: 10.2527/2000.7871930x

17 Itoh N., Koiwa M., Hatsugaya A., Yokota H., Taniyama H., Okada H. \& Kudo K. 1998. Comparative Analysis of Blood Chemical Values in Primary Ketosis and Abomasal Displacement in Cows. Journal of Veterinary Medicine Series A. 45(1-10): 293-298. DOI: 10.1111/j.1439-0442.1998.tb00830.x

18 Kawase T., Toyofuku M., Higashihara T., Okubo Y., Takahashi L., Kagawa Y., Yamane K., Mito S., Tamekiyo H., Otsuka M., Okimoto T., Muraoka Y., Masaoka Y., Shiode N. \& Hayashi Y. 2015. Validation of lactate level as a predictor of early mortality in acute decompensated heart failure patients who entered intensive care unit. Journal of Cardiology. 65(2): 164-170. DOI: 10.1016/j.jjcc.2014.05.006

19 Konturek P.C., Duda A. \& Brzozo T. 2000. Activation of Genes for Superoxide Dismutase, Interleukin-1ß, Tumor Necrosis Factor-a, and Intercellular Adhesion Molecule-1 during Healing of Ischemia-Reperfusion-Induced Gastric Injury. Scandinavian Journal of Gastroenterology. 35(5): 452-463. DOI: 10.1080/003655200750023697

20 Kwiecień S., T. Brzozowski \& S.J. Konturek. 2002. Effects of reactive oxygen species action on gastric mucosa in various models of mucosal injury. Journal of Physiology and Pharmacology. 53(1): 39-50.

21 LeBlanc S.J., Leslie K.E. \& Duffield T.F. 2005. Metabolic Predictors of Displaced Abomasum in Dairy Cattle. Journal of Dairy Science. 88(1): 159-170. DOI: 10.3168/jds.S0022-0302(05)72674-6

22 Maden M., Ozturk A.S., Bulbul A., Avci G.E. \& Yazar E. 2012. Acute-Phase Proteins, Oxidative Stress and Enzyme Activities of Blood Serum and Peritoneal Fluid in Cattle with Abomasal Displacement. Journal of Veterinary Internal Medicine. 26(6): 1470-1475. DOI: 10.1111/j.1939-1676.2012.01018.x

23 van Meirhaeghe H., Deprez P., van den Hende C. \& Muylle E. 1988. Plasma Glucose Clearance and Insulin Response in Cows with Abomasal Displacement. Journal of Veterinary Medicine Series A. 35(1-10): 221-228. DOI: 10.1111/j.1439-0442.1988.tb00026.x

24 van Meirhaeghe H., Deprez P., van den Hende C. \& Muylle E. 1988. The Influence of Insulin on Abomasal Emptying in Cattle. Journal of Veterinary Medicine Series A. 35(1-10): 213-220. DOI: 10.1111/j.1439-0442.1988.tb00025.x

25 Niehaus A.J. 2016. Surgical Management of Abomasal Disease. Veterinary Clinics of North America: Food Animal Practice. 32(3): 629-644. DOI: 10.1016/j.cvfa.2016.05.006

26 Ormazabal V., Nair S., Elfeky O., Aguayo C., Salomon C. \& Zuñiga F.A. 2018. Association between insulin resistance and the development of cardiovascular disease. Cardiovascular Diabetology. 17(1): 122. DOI: 10.1186/s12933018-0762-4 
27 Radcliffe R.M., Divers T.J., Fletcher D.J., Mohammed H. \& Kraus M.S. 2012. Evaluation of L-lactate and cardiac troponin I in horses undergoing emergency abdominal surgery. Journal of Veterinary Emergency and Critical Care. 22(3): 313-319. DOI: 10.1111/j.1476-4431.2012.00744.x

28 Silva Filho A.P., Mendonça C.L., Souto R.J.C., Silva R.J., Soares P.C. \& Afonso J.A.B. 2017. Indicadores bioquímico e hormonal de vacas leiteiras mestiças sadias e doentes durante o final da gestação e o início da lactação. Pesquisa Veterinária Brasileira. 37(11): 1229-1240. DOI: 10.1590/s0100-736x2017001100007

29 Singh V., Martinezclark P., Pascual M., Shaw E.S. \& O'Neill W.W. 2010. Cardiac biomarkers - the old and the new: a review. Coronary Artery Disease. 21(4): 244-256. DOI: 10.1097/MCA.0b013e328338cd1f

30 Soares G.S.L., Ribeiro A.C.S., Paula J.F.C., Souto R.J.C., Oliveira Filho E.F., Soares P.C., Mendonça C.L. \& Afonso J.A.B. 2019. Cardiac biomarkers and blood metabolites in cows with clinical ketosis Biomarcadores cardíacos e metabólitos sanguíneos em vacas com cetose clínica. Semina: Ciências Agrárias. 40(6): 3525-3540. DOI: 10.5433/1679-0359.2019v40n6Supl3p3525

31 Stengärde L., Holtenius K., Tråvén M., Hultgren J., Niskanen R. \& Emanuelson U. 2010. Blood profiles in dairy cows with displaced abomasum. Journal of Dairy Science. 93(10): 4691-4699. DOI: 10.3168/jds.2010-3295

32 Suzuki H., Nishizawa T., Tsugawa H., Mogami S. \& Hibi T. 2011. Roles of oxidative stress in stomach disorders. Journal of Clinical Biochemistry and Nutrition. 50(1): 35-39. DOI: 10.3164/jcbn.11-115SR

33 Valberg S.J. 2008. Skeletal Muscle Function. In: Kaneko J.J., Harvey J.W. \& Bruss M.L. (Eds). Clinical Biochemistry of Domestic Animals. 6th edn. San Diego: Elsevier, pp.459-484.

34 Varga A., Angelos J.A., Graham T.W. \& Chigerwe M. 2013. Preliminary investigation of cardiac troponin i concentration in cows with common production diseases. Journal of Veterinary Internal Medicine. 27(6): 1613-1621. DOI: $10.1111 /$ jvim. 12213

35 Wende A.R. \& Abel E.D. 2010. Lipotoxicity in the heart. Biochimica et Biophysica Acta (BBA) - Molecular and Cell Biology of Lipids. 1801(3): 311-319. DOI: 10.1016/j.bbalip.2009.09.023

36 van Winden S.C.L. \& Kuiper R. 2003. Left displacement of the abomasum in dairy cattle: recent developments in epidemiological and etiological aspects. Veterinary Research. 34(1): 47-56. DOI: 10.1051/vetres:2002060

37 Wittek T., Constable P.D. \& Furll M. 2004. Comparison of abomasal luminal gas pressure and volume and perfusion of the abomasum in dairy cows with left displaced abomasum or abomasal volvulus. American Journal of Veterinary Research. 65(5): 597-603. DOI: 10.2460/ajvr.2004.65.597

38 Zadnik T. 2003. A comparative study of the hemato-biochemical parameters between clinically healthy cows and cows with displacement of the abomasum. Acta Veterinaria. 53(5-6): 297-310. DOI: 10.2298/AVB0306297Z 